\title{
EFFECT OF MAIZE PRODUCTION ON POVERTY ALLEVIATION OF FARMERS IN EDO STATE, NIGERIA
}

\author{
Ahmadu, J.* and Edeoghon, C.O. \\ Department of Agricultural Economics and Extension Services, Faculty of Agriculture, \\ University of Benin, P.M.B. 1154, Benin City, Nigeria \\ ${ }^{*}$ Corresponding address: joseph.ahmadu@uniben.edu
}

\begin{abstract}
The high incidence of poverty in Nigeria calls for a concerted effort towards combating the problem. Maize production which is one of the major sources of livelihood to the rural poor may be one of the means to alleviating poverty among the poor populace. This study examined the effect of maize production on poverty alleviation of farmers in Edo State, Nigeria. A three-stage simple random sampling technique was employed to sample 180 maize farmers from the study area. Data were collected from the respondents using structured questionnaire. A total of 178 correctly completed copies of the questionnaire were used for analysis. Data analysis was done using descriptive statistics, poverty index, the Likert scale and t-test. The results of the study showed that the annual income and per capita income of the farmers without maize production were $\mathrm{A548,197.00}$ and $\mathrm{A} 215.00$ respectively but these significantly $(p<0.01)$ increased by \$169,016.00 and $\$ 66.00$ respectively when income from maize production was added. The incidence, depth and severity of poverty among the farmers without maize production were $97 \%, 63 \%$ and $40 \%$ respectively but these significantly $(p<0.01$ ) decreased to $70 \%, 39 \%$ and $16 \%$ respectively with maize production, accounting for $27 \%, 24 \%$ and $24 \%$ reduction respectively. Other perceived significant benefits derived from maize production included rare cases of hunger in the family, and ability to participate actively in social activities, among others. Thus, maize production in Edo State had contributed significantly to improving the income of the maize farmers and alleviating their poverty.
\end{abstract}

Keywords: Effect, Maize production, Poverty, Small-scale farmers, Benefits 


\section{INTRODUCTION}

Nigeria is a country that is blessed with abundant resources - agricultural, petroleum and human resources, as well as solid minerals. It is however pathetic that it is among the poorest countries of the world (World Bank, 2004; Ahmadu \& Alufohai, 2011 and World Bank, 2015). The low income level of most families is not adequate to provide for their basic needs. Thus, hunger, malnutrition and poverty continue to plague the country. Majority of the Nigeria's population worse hit by poverty are the rural dwellers who derive their livelihood from agriculture (World Bank, 2015), including maize production.

Poverty is a multidimensional phenomenon which is described as pronounced deprivation in well-being with the other aspects encompassing the psychological pain of being poor, a sense of vulnerability to insecurity and a sense of powerlessness vis-a-vis the state of societal institutions (Revenga et al., 2002 \& World Bank, 2004). It can also be viewed as a situation of low income, low consumption, and/or when measured standard of living is below a minimum acceptable level of poverty (Olaopa et al., 2006). Poverty can be defined in relative or absolute terms. Poverty alleviation is a process which improves the standard of living of the poor, thus, reducing the proportion of individuals or households who are living below an acceptable minimum standard of living. According to Kraai (2015), poverty alleviation aims at reducing the negative impact of poverty on the lives of poor people in a sustainable way.

Statistics show that there has been a remarkable progress on reducing poverty in the world over the past decades. Evidently, the percentage of the world's population living in extreme poverty (i.e. below US $\$ 1$ per day) decreased from $44 \%$ in 1981 and $37 \%$ in 1990 to $12.7 \%$ in 2012 (World Bank, 2012). Despite this progress, the population of people living in extreme poverty worldwide remains unacceptably high. Besides, the progress was not made in all the regions of the world. For instance, while the ratio of poverty for all the other regions of the world has been falling significantly since the 1980s, the ratio for Sub-Saharan Africa has been increasing (Kanayo, 2014). This indicates that a lot of work still needs to be done in the fight against poverty, especially in Sub-Saharan Africa, including Nigeria, where the challenge is becoming unbearable.

In Nigeria, poverty is on the increase despite the country's sixth position as the world largest oil exporter. The incidence and depth of poverty over the past few decades in the country continue to worsen (Ahmadu \& Alufohai, 2011), being worse than the rates in most countries of the world (Kanayo, 2014). The United Nations Development Programme (UNDP) Human Development Index (HDI) poverty ranking for Nigeria deteriorated from $142^{\text {nd }}$ position out of the 174 countries listed in 1998 (UNDP, 2002) to 152 nd position out of the 188 countries listed in 2015 (UNDP, 2016). The poverty incidence in the country increased from $54.4 \%$ in 2004 to $69 \%$ 
in 2010. Further statistics indicate that the increase in the proportion of the extremely poor between the 1980 and 2010 was sharper than that of the moderately poor (32.5\% as against 9.3\% respectively) (National Bureau of statistics, NBS, 2012), making the situation a pathetic one. The rural areas are the most affected. Evidently, poverty estimates in the rural areas in 2010 are as high as $73.2 \%$ and $66.1 \%$ for relative and absolute poverty respectively as against $61.8 \%$ and $52 \%$ respectively for the urban areas. On state basis in 2010 , poverty was highest in Sokoto State with relative and absolute poverty estimates of $86.4 \%$ and $81.2 \%$ respectively and lowest in Niger State with the estimates of $43.6 \%$ and $33.8 \%$ respectively. The relative poverty in Edo State stood at 72.5\% while the absolute poverty was 65.6\% in 2010 (NBS, 2012). These estimates are clearly indicative of the chronic and pathetic poverty situation the country has been subjected to. It is not surprising that Nigeria is witnessing high rates of crimes, social unrest and insurgency which are partly the upshot of poverty.

In an effort to curb the incidence of poverty as well as food insecurity in the country, successive governments embarked on various policies and programmes aimed at boosting agricultural production (Olatunji et al., 2012). This is because agriculture remains the major source of livelihood of majority of the rural poor in the country. Maize production may be one of the means of alleviating poverty among farmers. This is owing to the fact that maize is among the most important staple foods in Nigeria. It accounts for about two-third of the calorie intake of the country's population (Mohammed et al., 2013). Also, studies on maize in different parts of Nigeria show an increasing importance of the crop amidst growing utilization by food processing industries and livestock feed mills (Ogunsimi et al., 2005 and Jimoh et al., 2014). In most parts of Nigeria, the crop has grown to be a crop cultivated for commercial purpose to generate income (Oladejo and Adetunji, 2012) to improve the welfare of the farming populace. Thus, study on the contribution of maize production to poverty alleviation remains imperative. Many research works have been carried out on maize in Nigeria: but they have focused more on nutrient uptake and performance of the maize crop (Ekesiobi et al., 2015 and Aderibigbe et al., 2017), efficiency of resource use (Oluwatayo et al., 2008 and Kasim et al., 2014); and chemical and nutritional analysis (Sule et al., 2014). Studies on the contribution of maize production to welfare or alleviation of poverty remain scarce (Ogunsimi et al., 2005). This makes this study needful.

\section{Objectives of the study}

The general objective of the study was to examine the effect of maize production on poverty alleviation of farmers in Edo State of Nigeria. The specific objectives were to: examine the contribution of maize production to the income of maize farmers in the study area; estimate the 
relative poverty line among the farmers; determine the effect of maize production on the poverty status of maize farmers; and examine the perceived benefits derived from maize production.

\section{Hypotheses of the study}

The following hypotheses stated in the null form $\left(\mathrm{H}_{0}\right)$ were tested for the study:

1. There is no statistical significant difference in income of farmers with and without maize production.

2. The incidence, depth and severity of poverty among the farmers without income from maize production do not differ statistically from the poverty incidence, depth and severity of the farmers with income from maize production.

\section{METHODOLOGY}

\section{Study area and scope of the study}

The study was carried out in Edo State of Nigeria. The state has a total land area of 17,802 $\mathrm{km}^{2}$ and a population of $3,218,332$ people and is located between latitude $5^{\circ} 04^{\prime}$ and $7034^{\prime}$ North of the Equator and longitude $5^{\circ}$ 04' and 60 44' East of Greenwich Meridian (Edo State Government, 2012 and Brinkhoff, 2013). Administratively, the state is divided into three senatorial districts - Edo North, Edo Central and Edo South with five, six and seven Local Government Areas (LGAs) respectively. The state has tropical climate with thick vegetation cover, high rainfall and relative humidity. Agriculture is the major occupation of the inhabitants of the study area. Some of the major arable crops produced in the area are maize, rice, cassava, yam and cocoyam.

The study was restricted to the effect of maize production on poverty alleviation of maize farmers. The study covered the contribution of income from maize production to the well-being of the maize farmers and the poverty status of the farmers.

\section{Sampling technique and sample size}

A three-stage simple random sampling technique was employed for the selection of respondents. In the first stage of the sampling process, two LGAs were randomly selected from each senatorial district of the state to give six LGAs. This is because, maize production cuts across all the LGAs. Second, two communities were selected, also at random, from each LGA to give a total of 12 communities. The third and last stage was the application of the simple random sampling technique to select 15 maize-based farmers from each community giving rise to a total sample size of 180 respondents. However, a total of 178 correctly completed copies of questionnaire were used for analysis. 


\section{Data collection}

The data collected for the study were from primary source. The instrument for the collection of the primary data was a structured questionnaire. The data collected covered the quantities of inputs and output, unit prices of the inputs and output, income of the respondents, and ranked perception of respondents on the contribution of maize production to their welfare. Secondary data used for the study were mainly for literature purpose. The data for the study were collected in 2014.

\section{Data analysis}

Data analysis was done using descriptive statistics, relative poverty line and poverty index analyses, the Likert scale and t-test. The analysis was based on the assumption that any change in the income of the farmers was mainly due to their participation in maize production and nothing else.The analytical tools are discussed as follows:

Descriptive statistics: The descriptive statistics involved the use of means, frequency counts, percentages and standard deviation.

Relative poverty line analysis: The poverty line was defined based on the mean per capita income (MPCl) of the respondents. A relative approach (Coudouel et al., 2014) in which a respondent is regarded as poor relative to other respondents within the maize production industry in the study area was used. The poverty line was used to dichotomize the respondents into poor and non-poor. The respondents with per capita income less than the $\mathrm{MPCl}$ were classified as poor while those with per capita income equal to and greater than the $\mathrm{MPCl}$ as non-poor.

Poverty index analysis: The Foster-Greer-Thorbecke (FGT) poverty indexes were used to determine the incidence, depth and severity of poverty among the respondents. This analysis was based on the p-alpha $\left(P_{\alpha}\right)$ poverty measure proposed by Foster Greer and Thorbecke (1984) which is expressed as:

$$
P_{\alpha}=\frac{1}{N} \sum_{i=1}^{q}\left(\frac{z-g_{i}}{z}\right)^{\alpha}
$$

Where: $Z$ = Poverty line; $g_{i}=$ Per capita income of the ith farmer; $q=$ Number of respondents below the poverty line; $N=$ Sample size; $a=0,1$ and 2 which represent the incidence, depth and severity of poverty respectively. 
Likert scale: The perceived benefits derived from maize production were rated using a 5-point rating scale of strongly agree (5), agree (4), undecided (3), disagree (2) and strongly disagree (1). A mean score of $\geq 3.0$ was considered significant.

t-test: The t-test was used to test the hypotheses of the study. The t-test adapted from sOlayemi (1998) is expressed as:

$$
\mathrm{t}=\frac{\overline{\mathrm{X}}_{\mathrm{j} 2}-\overline{\mathrm{X}}_{\mathrm{j} 1}}{\frac{\mathrm{s}_{\mathrm{j} 2}+\mathrm{s}_{\mathrm{j} 1}}{\sqrt{\mathrm{N}}}} \ldots
$$

Where: $\mathrm{j}=1,2,3,4$ and 5 variables representing mean annual income, mean per capita income, poverty incidence, poverty depth and severity of poverty of respondents respectively;

$\overline{\mathrm{X}}_{\mathrm{j} 2}=$ Mean of the jth variable with maize production; $\overline{\mathrm{X}}_{\mathrm{j} 1}=$ Mean of the jth variable without maize production; $S_{j 2}$ and $S_{j 1}=$ Standard deviation of the jth variable with and without maize production respectively; $\mathrm{N}=$ Sample size.

\section{RESULTS AND DISCUSSION}

\section{Contribution of maize production to income of respondents}

Table 1 shows the average annual income of the respondents from maize production (average farm size: 1.4ha) and other income sources, as well as their per capita income. Without income from maize production, the farmers had average annual income from other sources of A548,197.00 while with maize production, the average annual income of the respondents increased to $\$ 717,213.00$, representing about $24 \%$ increase. Of all the sources of income available to the respondents, maize's contribution was the highest (24\%). Similarly, the average per capita income of the farmers increased from $\$ 215.00$ without maize production to $\$ 281.00$ with maize production. This also accounted for about $24 \%$ increase.

The increases in the average annual income and per capita income of the farmers were both significant at $1 \%$ level of significance. Thus, the stated null hypotheses for both annual income and per capita income were rejected. This shows that maize production, though on a smallscale level, had contributed significantly to improving both the general income level and the per capita income of the respondents. The contribution of maize production to the income of the maize farmers was also observed by Audu and Aye (2014) when they asserted that maize is not only a source of income to its producers but it provides employment to millions of people engaged in its production. 


\section{Poverty line of the respondents}

The relative poverty line of the farmers was defined based on their mean per capita income (Table 1). Without income from maize production, the poverty line of the farmers was estimated at 215.00. When income from maize production was added, the poverty line was put at A281.00. Thus, farmers with mean per capita income (MPCl) less than the poverty lines were designated poor while those with $\mathrm{MPCl}$ equal to or greater than the poverty lines non-poor. This analysis gave the proportion of the respondents living below the poverty line (poverty incidence).

Table 1: Average Income from Maize Production and other Productive Activities, per Capita Income and Poverty Line of Respondents

\begin{tabular}{|c|c|c|c|}
\hline Category & $\begin{array}{l}\text { Mean } \\
\text { annual } \\
\text { income (A) }\end{array}$ & $\begin{array}{l}\text { Percentage of } \\
\text { total annual } \\
\text { income }(\%)\end{array}$ & $\begin{array}{l}\text { Mean per } \\
\text { capita } \\
\text { income } \mathrm{N} \text { ) }\end{array}$ \\
\hline \multicolumn{4}{|l|}{$\begin{array}{l}\text { Income from other productive activities } \\
\text { without maize production }\end{array}$} \\
\hline Livestock & $50,800.00$ & 7.08 & \\
\hline Other crops & $126,740.00$ & 17.67 & \\
\hline Marketing (trading) & $83,943.00$ & 11.70 & \\
\hline Labour hiring services & $79,726.00$ & 11.12 & \\
\hline Civil service & $118,780.00$ & 16.56 & \\
\hline Professional services & $59,375.00$ & 8.28 & \\
\hline Rental services & $11,333.00$ & 1.58 & \\
\hline Arts and Crafts & $17,500.00$ & 2.44 & \\
\hline Total income without maize production & $548,197.00$ & 76.43 & 215.00 \\
\hline Income from maize production & $169,016.00$ & 23.57 & 66.15 \\
\hline Total income with maize production & $717,213.00$ & 100.00 & 281.00 \\
\hline $\begin{array}{l}\text { t-ratio of the difference between mean } \\
\text { income values with and without maize } \\
\text { production }\end{array}$ & $4.27^{*}$ & & $4.27^{\star}$ \\
\hline \multicolumn{4}{|l|}{ Poverty line } \\
\hline Without income from maize production & & & 215.00 \\
\hline With income from maize production & & & 281.00 \\
\hline
\end{tabular}

${ }^{*}$ Significant at $1 \%$ level of significance: $\mathrm{t}_{0.01}(\mathrm{df}=177)=2.33$ 


\section{Incidence, Depth and Severity of Poverty among the Maize Farmers}

The incidence, depth and severity of poverty among the maize farmers are presented in Table 2. Without income from maize production, the farmers had poverty incidence (the percentage of farmers living below the poverty line) of $97 \%$ and this decreased to $70 \%$ when income from maize production was added, representing $27 \%$ reduction. This result compares favourably with the findings of NBS (2012) which reported relative poverty of $72.5 \%$ and $73.2 \%$ for Edo State and Nigeria respectively. The poverty depth of the farmers without and with income from maize production was $63 \%$ and $39 \%$ respectively, indicating that maize production contributed $24 \%$ reduction in the poverty gap of the farmers. This implies that without maize production, the amount required to be given to each of the poor farmers to lift them out of poverty was $63 \%$ of the poverty line and this requirement decreased by $24 \%$ when income from maize production was added. The severity of poverty among the farmers was as high as $40 \%$ without maize production and this decreased to $16 \%$ with maize production. This indicates a more disperity (distance) in poverty level among the farmers without income from maize production than when income from maize production was added.

The results of the t-test analysis showed that the decreases in the incidence, depth and severity of poverty among the farmers due to income from maize production were all significant at $1 \%$ level of significance. This means that the income from maize production had caused significant reduction in the poverty level of the respondents. Therefore, the null hypothesis in each case is rejected.

Table 2: Poverty Incidence, Depth and Severity among the Maize Farmers

\begin{tabular}{|c|c|c|c|c|}
\hline Poverty index & $\begin{array}{l}\text { Without maize } \\
\text { production }\end{array}$ & $\begin{array}{l}\text { With maize } \\
\text { production } \\
\text { (B) }\end{array}$ & $\begin{array}{l}\text { Difference } \\
\text { between with } \\
\text { (B) and without } \\
\text { (A) maize } \\
\text { production } \\
\text { Rate }\end{array}$ & $\begin{array}{l}\text { t-ratio of } \\
\text { statistical } \\
\text { difference } \\
\text { between with } \\
\text { and without } \\
\text { maize } \\
\text { production }\end{array}$ \\
\hline $\begin{array}{l}\text { Poverty } \\
\text { incidence }\end{array}$ & 0.97 & 0.70 & 0.27 & $4.80^{*}$ \\
\hline Poverty depth & 0.63 & 0.39 & 0.24 & $4.27^{*}$ \\
\hline $\begin{array}{l}\text { Severity of } \\
\text { poverty }\end{array}$ & 0.40 & 0.16 & 0.24 & $4.27^{\star}$ \\
\hline
\end{tabular}

t-test table value at $1 \%$ level of significance: $2.33 \quad{ }^{*}$ Significant at $1 \%$ level of significance 


\section{Perceived benefits derived from maize production}

Table 3 shows the perceived benefits derived from maize production by the respondents. The perception of the respondents on the benefits indicated that 11 out of the 15 benefits under consideration were significant (mean score $\geq 3.00$ ). The most important benefit was that of rare cases of hunger in the families of the respondents (mean score $=4.61$ ). This was followed by the ability to participate actively in social activities (mean score $=4.29$ ), tremendous increase in income (mean score $=4.25$ ) and ability to pay house rent with ease (mean score $=4.25$ ). Other significant benefits in descending order of significance were increased in the number of electronics and other household facilities, purchase of clothes for self and family with ease, establishment and/or expansion of business, among others. These benefits indicate that maize production had contributed significantly to improvement in the well-being of the maize farmers. Some of these benefits were also reported by Ahmadu and Alufohai (2011).

Table 3: Perceived Benefits Derived from Maize Production

\begin{tabular}{ll}
\hline Benefits & Mean score \\
\hline My income has increased tremendously & $4.25^{*}$ \\
Able to increase my farm size & $3.39^{*}$ \\
My family hardly suffers from hunger & $4.61^{*}$ \\
Better access to medical services & $3.44^{*}$ \\
Establishment and/or expansion of business & $4.08^{*}$ \\
Able to build my own house & 1.97 \\
Able to pay house rent with ease & $4.25^{*}$ \\
Able to relocate to better rented apartment & $3.29^{*}$ \\
Payment of children school fees with ease & $3.79^{*}$ \\
Trained myself in school & 1.94 \\
I can now participate actively in social activities & $4.29^{*}$ \\
I can now afford to buy clothes for myself and family with ease & $4.10^{*}$ \\
Increase in the number of electronics and other household facilities & $4.14^{*}$ \\
Able to buy vehicles & 2.83 \\
Better access to information/communication facilities & 2.92 \\
\hline
\end{tabular}

* Significant (Mean score $\geq 3.0$ ) 


\section{CONCLUSION AND RECOMMENDATIONS}

The study has established that maize production, though carried out on small-scale level, contributed significantly to improvement in the well-being of maize farmers in Edo State, Nigeria. Specifically, the significant increase in income of the farmers due to maize production led to significant decrease in their poverty incidence, depth and severity. Besides, other numerous benefits derived from maize production were perceived by the respondents. Thus, maize production is a vital enterprise for poverty alleviation. Based on the findings of the study, it is hereby recommended that the unemployed youths should be encouraged and empowered to go into maize production since it is a business venture that could increase income and alleviate poverty.

\section{ACKNOWLEDGEMENTS}

We wish to express our profound gratitude to Tertiary Education Trust Fund (TETFund) for providing the grant to fund this study. We also thank University of Benin, Benin City, Nigeria through which the grant was administered.

\section{REFERENCES}

Aderibigbe, S.G., Sakariyawo, O.S., Kasali, A.O. (2017). Performance of Maize (zea mays) Cultivars as influenced by Grade and Application Rate of Organo-Mineral Fertilizer in a Transitory Rain Forest. Agrosearch 17 (2): 78 - 98.

Ahmadu, J. \& Alufohai, G.O. (2011). Effect of Yam Production on Poverty Alleviation of Famers in Ika Area of Delta State, Nigeria. International Journal of Agricultural Economics and Extension Services1(1): 148 - 160.

Audu, V.I. \& Aye, G.C. (2014).The Effects of Improved Maize Technology on Household Welfare in Buruku, Benue State, Nigeria. Cogent Economics and Finance2: 1 - 10. Available online at: http://dx.doi.org/10.1080/23322039,2014.960592

Brinkhoff T (2013). Nigeria: Administrative Division - the Population of the States and LGAs. City Population, Accessed on 29 th $^{\text {th }}$ December, 2014 from: http://www.citypopulation.de/php/nigeria-admin.php

Coudouel, A.; Hentschel, J.S. \& Wodon, Q.T. (2014). Poverty Measurement and Analysis. Site Resources, World Bank. Available online at: siteresources.worldbank.org/INTPRS1 /Resources 383606- 
Edo State Government (2012). Geography of Edo State. www.edostate.gov.ng/geography, accessed $12^{\text {th }}$ March, 2013.

Ekesiobi, L.A., Ndukwe, O.O., Ezeano, C.L., Odukwe, K.A. and Nnabuife, E.L.C. (2015). Influence of complementary rate of poultry manure and urea fertilizers on growth and yield of maize (zea mays L.) in South Eastern Agro-ecology zone: International Journal of Applied Science and Engineering, 3(1): 8 - 13.

Foster, J.; Greer, J. \& Thorbecke, E. (1984). A Class of Decomposable Poverty Measures. Econometrica 52: $761-766$.

Jimoh, W.A.; Sodamola, M.O.; Ayeloja, A.A.; Oladele-Bukola, M.O. and Shittu, M.O. (2014). The Influence of Replacing Maize with Chrysophyllum Albidum Seed Meal on Growth Response and Nutrient Utilization in Clariasgariepinus. Agrosearch 14 (1): $54-61$. Available online at: https://www.ajol.info/index.php/agrosh/issue/view/11367

Kanayo, O. (2014). Poverty Incidence and Reduction Strategies in Nigeria: Challenges of Meeting 2015 Millennium Development Goal (MDG) Targets. Journal of Economics5 (2): 201 217. Available online at: www.krepublishers.com/02-Journals/JE/JE-05-0-000-14-web

Kasim, I., Mad Nasir, S., Rusli, Y. and Alias, B.R. (2014). Technical Efficiency in Maize Production and its Determinants: A Survey of Farms across Agro-Ecological Zones in Northern Nigeria. Trends in Agricultural Economics, 7: 57 - 68.

Kraai, N. (2015). What is Poverty Relief, Poverty Alleviation, Poverty Reduction and Poverty Eradication? National Development Agency (NDA), Accessed online at: www.nda.org.za/docs/what do we mean by poverty.pdf.

Mohammed, A.B.; Ayanlere, A.F.; Ibrahim,U. and Lawal, A.M. (2013). Economic Analysis of Maize Production in Ogori-Magongo Local Government Area of Kogi State, Nigeria. Journal of Agricultural Economics and Development, 1(3).

National Bureau of Statistic (NBS) (2012). The Nigeria Poverty Profile 2010 Report. Press briefing by the Statistician-General of the Federation/Chief Executive Officer, NBS held at the Conference Room, $5^{\text {th }}$ Floor, NBS Headquarters, Abuja on 13 th February, Accessed online at: www.proshareng.com/reports/Achives 
Ogunsimi, I.O.; S.O. Ewuola \& A.G. Daramola (2005). Socio-Economic Impact Assessment of Maize Production Technology on Farmers Welfare in South-West, Nigeria. Journal of Central European Agriculture 6 (1): $15-26$.

Oladejo, J.A. and Adetunji, M.O. (2012). Economic Analysis of Maize (zea mays I) Production in Oyo State of Nigeria. Agricultural Science Research Journals 2 (2): 77 - 83.

Olaopa, R.O.; Elumilade, O.D. \& Asaolu, O.T. (2006). Creating Wealth through Poverty Alleviation: An Assessment of the National Economic Empowerment Development Strategy in Nigeria. Research Journal of International Studies xvii (F): 1 - 10.

Olatunji, G.B.; Omotesho, O.A.; Ayinde, O.E. and Adewumi, M.O. (2012). Empirical Analysis of Agricultural Production and Inflation Rate in Nigeria (1970 - 2006). Agrosearch 12 (1): 21 - 30. Available online at: https://www.ajol.info/index.php/agrosh/issue/view/9345

Olayemi, J.K. (1998). Elements of Applied Econometrics. Pp. 65 - 80. Ibadan, Nigeria: Elshaddai Global Ventures Ltd.

Oluwatayo, I.B.; Sekumade, A.B. \&Adesoji, S.A. (2008). Resource Use Efficiency of Maize Farmers in Rural Nigeria: Evidence from Ekiti State. World Journal of Agricultural Science 4 (1): 91 - 99. Available online at: idosi.org/wjas/wjas4(1)/17.pdf

Sule, E.I.; Umoh, V.J.; Whong, C.M.Z; Abdullahi, I.O. and Alabi, O. (2014). Chemical and Nutritional Value of Maize and Maize Products obtained from selected Markets in Kaduna State, Nigeria. African Journal of Food Science and Technology 5(4): 100 - 104.

United Nations Development Programme, UNDP (2002). Human Development Report, New York, Oxford University Press.

United Nations Development Programme, UNDP (2016). Human Development Report. Retrieved from hdr.undp.org/sites/all/themes/hdr-theme/country-notes/NGA.pdf

Venga, A; Ringold, D. and Tracy, W.M. (2002). Poverty and Ethnicity: A Cross-Country Study of Roma Poverty in Central Europe. World Bank Technical Paper, No. WTP 531, Washington D.C.: The World Bank. Retrieved from http:/l documents.worldbank.org/urated/en/839821468759298610/Poverty-and-ethnicity-across-country-study-of-ROMA-poverty-in-Central-Europe

World Bank (2004). Making Services Work for the Poor People- Overview. World Development Report,Washington D.C.: World Bank Group. Retrieved from 
http://documents.worldbank.org/curated/en/527371468166770790/World-DevelopmentReport-2004-Making-services-work-for-poor-people-Overview

World Bank (2012). Poverty Overview. The World Bank, Accessed online at: http://www.worldbank.org/en/topic/poverty

World Bank (2015). Poverty Overview. The World Bank. Retrieved from http://www. worldbank.org/en/topic/poverty/overview 